\title{
The PhD Project: How Successful Is It?
}

\author{
Bill N. Schwartz, PhD, CPA, USA \\ Satina V. Williams, Marist College, USA \\ W. Darrell Walden, University of Richmond, USA
}

\begin{abstract}
The PhD Project's mission to diversify the work force by increasing the diversity of business school faculty is quite admirable, but is the Project successful? To gather insights toward responding to that question and to offer suggestions, we reviewed three of the Project's objectives that relate most closely to minority doctoral students and faculty members. We examined the Project's website, held discussions with Project staff members, and surveyed Project alumni. Among the myriad of PhD Project activities, the most important are its annual November conference for potential doctoral students and its annual minority doctoral student association meetings for each of five academic disciplines (accounting, finance, information systems, management and marketing). The annual conference attracts between 350 and 400 individuals from which about $10 \%$ enroll in doctoral programs each year. The doctoral student associations have over 1,400 members of which some 400 are current doctoral students and the others are faculty members. The Project is making significant progress toward accomplishing its mission and objectives. Areas where the Project could improve its accomplishments include identifying why those who have considered enrollment have not done so, placing greater emphasis on teaching and service at minority doctoral student association conferences, and strengthening mentoring relationships.
\end{abstract}

Keywords: Doctoral Education; Diversity; Faculty; PhD Project

\section{INTRODUCTION}

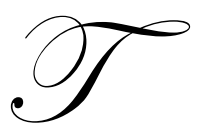

he KPMG Foundation established the PhD Project as one way to remedy the lack of diversity among students in business schools. Using a support network of minority doctoral student associations, financial support, and vast resources, the $\mathrm{PhD}$ Project attracts African-Americans, Hispanic Americans, and Native Americans to business programs and supports them through the doctoral process to completion. Ninety percent of doctoral students associated with the PhD Project complete their program compared to the national average of $75 \%$ (Milano 2008, 78). The purpose of this study is to ask the questions: 1) Is the Project succeeding? and 2) How can it improve? We attempt to provide some insights about these questions.

According to Milano $(2008,78)$ the management of American business will be diversified when graduating classes of business schools are diversified. Organizations that recognize the changing U.S. demographics and benefits of a diverse workforce understand the importance of attracting and retaining the best talent. PhD Project alumni are an important component of the strategy to put more faculty of color in the front of the classroom and attract more minority college students to a business major. Increasing the number of minority business majors increases the probability that organizations will reach and maintain their goal of diversification. Without endeavors to increase the number of minority business majors, diversification remains only a lofty ambition.

\section{THE PHD PROJECT MISSION AND OBJECTIVES}

The PhD Project's mission is 'to increase the diversity of corporate America by increasing the diversity of business school faculty. We attract African-Americans, Hispanic-Americans and Native Americans to business PhD programs, and provide a network of peer support on their journey to becoming professors. As faculty, they serve as role models attracting and mentoring minority students while improving the preparation of all students for our diverse workplace and society'. (www.PhDproject.org) 
The Project lists seven objectives on its website. The objectives are not mutually exclusive. We have chosen to examine the first three objectives that relate to faculty members directly (full list appears in Appendix A).

1. Inform and educate minorities about all aspects of a business doctoral program and encourage them to follow their dream of becoming a professor

2. Provide a nurturing support network for minorities as they navigate their doctoral program

3. Increase the number of minority business professors who can function as role models and mentors

To examine these objectives, we reviewed the materials on the website (www.PhDproject.org) and spoke at length with individuals working with the $\mathrm{PhD}$ Project. We then surveyed $\mathrm{PhD}$ Project alumni to get their views on subjects relating to these objectives.

\section{WHAT THE PHD PROJECT DOES}

Objective \#1 - Inform and Educate Minorities about All Aspects of A Business Doctoral Program and Encourage Them to Follow Their Dream of Becoming A Professor

The PhD Project works with a marketing plan that utilizes several very significant mechanisms to accomplish this objective. One is the "Supply Alliance," which includes 54 professional and academic organizations with access to minorities. The Project supplies these organizations with materials for mailings in hard copy, as well as email, to encourage minorities to visit the PhD Project website, consider pursuing a doctoral degree and, if interested in learning more about doctoral education and an academic career, apply to the Annual PhD Project Conference for aspiring doctoral students.

The Project also works through the almost 1,500 members of its minority doctoral student associations (described below). It encourages the members to actively recruit top minority students to consider graduate education. The Project makes available materials to assist with these endeavors.

Each year Project representatives visit college campuses to speak with faculty members and their top students about graduate education. The representatives also work with chapters of student honorary fraternities, such as Beta Gamma Sigma and Beta Alpha Psi, to identify individuals for the Project to contact. Project staff members also attend 20 to 30 conferences of such organizations as the National Association of Black MBAs, National Society of Hispanic MBAs, National Association of Black Accountants, American Indian Business Leaders, and The Association of Latino Professionals in Finance and Accounting, to inform attendees about doctoral studies in business and distribute literature.

The Project utilizes a media plan to promote the Project in both print and on-line outlets. The latter includes Google, Facebook, Diversity/Careers.com and Inside Higher Ed. Print matter include Biz Ed, Black MBA Magazine, Diversity, Inc.,Tribal College Journal and others. The Project also places items in publications at conferences such as American Indian Business Leaders, NABA, and Hispanic MBA.

The PhD Project's major vehicle is its annual conference. Each November in Chicago, the PhD Project conducts a two-day conference with plenary and break-out sessions and guest speakers. Its purpose is to provide information to encourage minorities to consider entering business PhD programs. The conference began in 1994 when 266 individuals attended. Attendance has risen to well over 400 and has averaged 366 for the 16 years through 2009. Project representatives determine from attendees where they learned about the conference.

We computed a "batting average"; i.e., what proportion of the attendees enrolled in doctoral programs. Almost $10 \%$ of the attendees enrolled in doctoral programs since the conference's inception. The percentage was slightly higher initially (over 11\%), but the first two years were high with a high dropout rate. During the last decade, the percentage has been rather constant at around 9\%. The last two years have been a bit lower, but for some individuals it can take several years to make a decision about enrollment. Consequently, the percentages for these years ultimately may be quite similar to those in the past. 
The PhD Project's website also provides links to AACSB-accredited business schools that offer doctoral degrees and many organizations who offer scholarships for minorities. Among others, they include the American Association of University Women, the American Institute of CPAs, American Marketing Association, Elon University, Hispanic Scholarship Fund, KPMG Foundation, Native American Finance Officers Association, National Black MBA PhD Fellowship, etc.

Objective \#2 - Provide A Nurturing Support Network for Minorities as They Navigate Their Doctoral Program

The PhD Project has established one major mechanism for accomplishing objective \#2 - the Minority Doctoral Student Associations (DSAs). The Project created the DSAs in 1994 "to sustain a high level of commitment and a sense of connection among minority business doctoral students" (www.PhDproject.org). There are five minority doctoral student associations - Accounting, Finance, Information Systems, Management, and Marketing. They have grown to a membership of 1,446 as of 2010, with 1,061 faculty members and 385 students. Faculty membership has been increasing while student membership has remained constant within a narrow range as new students replace those who complete their programs and become faculty, along with those who discontinue their studies.

The Project's programs for doctoral students supplement the students' education with activities that other doctoral students may not experience. The Project offers its participants opportunities to network with experienced faculty and journal editors. Each year, the Project hosts 2 to 2-1/2 day DSA conferences in conjunction with professional conferences. For example, in 2010, the Project Accounting Doctoral Student Association Conference met in San Francisco and the American Accounting Association's annual meeting also convened there, allowing accounting doctoral students to participate in the doctoral student association conference and the professional meeting. The Marketing Doctoral Student Association Conference met in Boston before the American Marketing Association meeting. To attend, an individual must be a PhD Project student member but does not have to be a member of a minority DSA. For 2010, attendance for doctoral students ranged from 21 in finance to 91 in management and for new faculty members, from three in information systems to 14 in management. While a few sessions relate to teaching, external and internal service, and job search, the main topic at all the meetings is scholarship.

During the DSA conferences, faculty members conduct plenary and break out sessions to help students appreciate the academic environment they will enter after completing their studies. During the professional association meetings that follow, doctoral students can attend scheduled sessions, such as paper presentations, that enhance their knowledge of various research topics. Students that are active with the PhD Project may attend the key professional meetings for their discipline years before many of their majority counterparts. Students also can increase their support network by interacting with faculty outside of their doctoral program. The Project covers all expenses for the students for both the DSA conference and the professional discipline's meeting.

Objective \#3 - Increase the Number of Minority Business Professors Who can Function as Role Models and Mentors

The third objective of the PhD Project is to increase the number of minority business professors who can be role models and mentors. However, the Project can accomplish this objective only if the doctoral programs prepare their students to assume the role of faculty member. These students are enrolled in the same programs as those who are not involved with the PhD Project and are subject to the same conditions. The literature indicates there is a concern that graduate students are not and, for the most part, do not see themselves as prepared for the role and responsibilities of academe (Austin, 2002, Gaff, 2002; Golde and Dore, 2001; Greenberg, 2006; Mitchell, 2007; Newman, 1999).

Mentoring stands out as one of the most important efforts. When mentored, a doctoral student receives assistance in their development and learns about the process of becoming an assistant professor (Heggins, 2004). In mentor relationships, experienced faculty members transfer knowledge to students preparing to join academe (Murdock 2006). According to DeNeef (2002), mentoring programs make a difference for most participants in the initial years of faculty membership. 
Through the DSA, the PhD Project encourages doctoral students to participate in mentorship programs with faculty members and to consider joint research opportunities with faculty and other doctoral students. The $\mathrm{PhD}$ Project also has established the PhD Project Networking site (www.MyPhDNetwork.org). The Network allows doctoral students to connect with other doctoral students, alumni, and prospective candidates and can create another avenue of support for doctoral students.

Thus, the Project has put in place two mechanisms to bring faculty members and doctoral students together. Anecdotal evidence suggests that some relationships exist. However, the Project has no data that demonstrate the quantity of mentor-mentee relationships and the quality of those relationships. The DSA meetings shows only one session dedicated to mentoring but no individuals serving as coordinators or leaders in trying to encourage and arrange such relationships.

In short, the PhD Project conducts quite a few activities to help accomplish its objectives. The Project has a mailing program for promoting and disseminating information, company contacts to help attract applicants, and utilizes print and on-line avenues extensively. The Project hosts an annual meeting to attract and then inform individuals about doctoral studies and a series of active organizations (DSAs) to help minority faculty members succeed. However, are these efforts successful? That is the subject for our study.

\section{RESEARCH METHOD}

With the assistance of the PhD Project, we asked alumni, who graduated within the last ten years, to complete an on-line survey. The $\mathrm{PhD}$ Project alumni consisted of 869 individuals (237 faculty members in accounting, 60 in finance, 128 in information systems, 274 in management, and 170 in marketing). The majority (76\%) of PhD Project alumni were African-Americans. We received surveys from $206 \mathrm{PhD}$ Project alumni (24\%).

\section{Measures}

We asked the $\mathrm{PhD}$ Project alumni to respond to items directly related to the $\mathrm{PhD}$ Project or its mission, such as "How important was the $\mathrm{PhD}$ Project in your decision to pursue a $\mathrm{PhD}$ in business?" (1=not at all important to 7=very important), "The PhD Project network of peer/mentor support was important in helping me select my first full-time faculty position after completing my $\mathrm{PhD}$ program" ( $1=$ strongly disagree to $7=$ strongly agree), and "How many minority undergraduate students have you mentored since completing your $\mathrm{PhD}$ program?"

\section{RESULTS}

\section{Demographics}

Demographics appear in Table 1. Most of the respondents are assistant professors (59\%) and not tenured (68\%). The respondents' academic disciplines are Accounting (37\%), Finance (6\%), Information Systems (16\%), Marketing (15\%) and Management (26\%). Most are females (58\%) between the ages of 36 and $55(86 \%)$, married $(62 \%)$, and African-American (80\%). On average, they received their $\mathrm{PhD}$ degree seven years ago and stayed in their first faculty position an average of 5.51 years.

\section{Institutional Characteristics}

Institutional characteristics appear in Table 2. The vast majority of respondents work at predominately white institutions (74\%), classify their employers as research-oriented (53\%), AACSB-accredited (74\%), and doctoral granting $(63 \%)$.

\section{PhD Project Objectives}

Objectives of the $\mathrm{PhD}$ Project and related survey items appear in Table 3. The PhD Project's first objective is to inform and educate minorities about all aspects of a business doctoral program. When rating the importance of the $\mathrm{PhD}$ Project in their decision to pursue a doctorate in business, 50\% deemed the PhD Project as important or very important $($ mean $=4.17)$. 
Table 1: Demographic data $(\mathrm{N}=206)$

\begin{tabular}{|c|c|c|c|}
\hline Academic Rank & $\mathbf{N}(\%)$ & Marital Status & $\mathbf{N}(\%)$ \\
\hline Assistant & $112(59)$ & Married & $115(62)$ \\
\hline Associate & $52(27)$ & Divorced/Single & $71(38)$ \\
\hline Full & $13(7)$ & & \\
\hline Other & $13(7)$ & & \\
\hline \multicolumn{2}{|l|}{ Tenure Status } & \multicolumn{2}{|l|}{ Ethnicity } \\
\hline Yes & $130(68)$ & Black/African American & $150(80)$ \\
\hline \multirow[t]{3}{*}{ No } & $60(32)$ & Hispanic/Latino & $30(16)$ \\
\hline & & Native American & $3(2)$ \\
\hline & & Multiracial & $4(2)$ \\
\hline \multicolumn{2}{|l|}{ Academic Disciplines } & \multicolumn{2}{|l|}{ Years Since PhD } \\
\hline Accounting & $70(37)$ & \multirow[t]{5}{*}{ Mean } & 7 years \\
\hline Finance & $11(6)$ & & \\
\hline Information Systems & $29(16)$ & & \\
\hline Management & $49(26)$ & & \\
\hline Marketing & $28(15)$ & & \\
\hline \multicolumn{2}{|l|}{ Gender } & \multicolumn{2}{|l|}{ Years in First Position } \\
\hline Female & $110(58)$ & \multirow{8}{*}{$\begin{array}{l}\text { Mean } \\
\text { Standard Deviation }\end{array}$} & \multirow{8}{*}{$\begin{array}{l}5.51 \\
3.17\end{array}$} \\
\hline Male & $79(42)$ & & \\
\hline \multicolumn{2}{|l|}{ Ages } & & \\
\hline Under 31 & $3(2)$ & & \\
\hline $31-35$ & $17(9)$ & & \\
\hline $36-45$ & $79(43)$ & & \\
\hline $46-55$ & $62(33)$ & & \\
\hline over 55 & $24(13)$ & & \\
\hline
\end{tabular}

Table 2: Institution Characteristics

\begin{tabular}{|l|c|l|c|}
\hline Classification & & Type & \\
\hline Historically Black College or University & $35(19)$ & Research & $100(53)$ \\
Traditionally Hispanic & $13(7)$ & Teaching & $88(47)$ \\
Primarily White & $137(74)$ & & \\
\hline Accreditation & & PhD Granting & $112(63)$ \\
\hline AACSB & $168(74)$ & Yes & $65(37)$ \\
ACBSP & $60(26)$ & No & \\
\hline
\end{tabular}

Table 3: Selected Objectives of the PhD Project

\begin{tabular}{|c|c|c|c|c|}
\hline & Rating & \# & $\%$ & Mean \\
\hline \multicolumn{5}{|c|}{$\begin{array}{l}\text { 1. Objective-Inform and educate minorities about all aspects of a business doctoral program and encourage minorities to follow } \\
\text { their dream of becoming a professor. }\end{array}$} \\
\hline $\begin{array}{l}\text { How important was the PhD Project in your decision to pursue } \\
\text { a PhD in business? ( } 1=\text { not important, } 7=\text { very important })\end{array}$ & $\begin{array}{l}\text { Important (5-7) } \\
\text { Neither (4) } \\
\text { Not important (1-3) }\end{array}$ & $\begin{array}{l}88 \\
17 \\
72\end{array}$ & $\begin{array}{l}50 \\
10 \\
40\end{array}$ & 4.17 \\
\hline \multicolumn{5}{|c|}{ 2. Objective-Provide a nurturing support network for minorities as they navigate their doctoral program. } \\
\hline $\begin{array}{l}\text { The PhD Project network of peer/mentor support was } \\
\text { beneficial while in my PhD program. (1=strongly disagree, } 7= \\
\text { strongly agree) }\end{array}$ & $\begin{array}{l}\text { Agree (5-7) } \\
\text { Neither (4) } \\
\text { Disagree (1-3) }\end{array}$ & $\begin{array}{c}144 \\
7 \\
23\end{array}$ & $\begin{array}{c}83 \\
4 \\
13\end{array}$ & 5.87 \\
\hline \multicolumn{5}{|c|}{ 3. Objective-Increase the number of minority business professors who can function as role models and mentors. } \\
\hline $\begin{array}{l}\text { How many minority undergraduate students have you } \\
\text { mentored since completing your PhD program? }\end{array}$ & $\begin{array}{l}\text { More than } 5 \\
1 \text { to } 5 \\
\text { None }\end{array}$ & $\begin{array}{l}98 \\
54 \\
27\end{array}$ & $\begin{array}{l}55 \\
30 \\
15\end{array}$ & \\
\hline
\end{tabular}

The PhD Project also strives to provide a nurturing, supportive network for doctoral students. With a mean score of 5.87, $144(83 \%)$ agreed or strongly agreed they benefited from the PhD Project's network of peer/mentor support during their doctoral studies. Another objective of the PhD Project is to have more minority faculty mentor 
minority students. Most (85\%) indicated that they have mentored at least one minority undergraduate students since completing their $\mathrm{PhD}$ program.

\section{DISCUSSION AND RECOMMENDATIONS}

The PhD Project provides both tangible and intangible benefits. Clearly the Project makes a major contribution toward its mission of diversifying the workplace and, for our particular interest, business faculties. From that perspective, the Project accomplishes a great deal.

Evaluating these benefits is difficult. For tangible activities, there are no external bases for comparison. In terms of the first objective (to inform and educate minorities about all aspects of a business doctoral program and encourage them to follow their dream of becoming a professor), the Project expends a great deal of effort through a number of vehicles. All are commendable and the Project attempts to monitor them to see to what extent they are worthwhile.

Their major effort is toward their annual November conference. We computed a "batting average" and found that around $10 \%$ of the attendees enter a doctoral program. We suggest that the Project should do more to understand the reasons why the other $90 \%$ chose not to enter doctoral programs. A follow-up email or hard-copy questionnaire to that group might identify areas where the Project could place emphasis and help increase their batting average. Follow-up telephone calls to select a sample of respondents could help make the responses more meaningful. Over several years, such data could make the conference schedule of events more productive.

The second objective (to provide a nurturing support network for minorities as they navigate their doctoral program) and the third objective (to increase the number of minority business professors who can function as role models and mentors) are closely related. Establishing minority doctoral student associations and the project network are wonderful ways to provide avenues for individuals to continue relationships with peers and mentors.

We noted that the major theme of the DSA meetings is research. Certainly, scholarship frequently is the determining factor in tenure and continuing appointment decisions. However, teaching and service are part of the decision process, too. For example, unless DSA members have teaching experience, they may need guidance in developing syllabi, preparing exams, balancing classroom preparation time with the need for arranging blocks of time to work on scholarship, understanding student attitudes, and other matters. It also is very important to help DSA members learn how to deal with the, at times, extensive service requests they receive. DSA meetings should consider allocating more time for teaching and service issues.

Based on the alumni survey, it is clear that Project alumni have participated in mentoring activities and feel it was beneficial. They also report they have mentored undergraduate students, which is another indication that the alumni see value in mentoring. However, we feel that the DSAs could do more in the area of mentoring. The Project does a great deal to help increase the number of minority students in doctoral programs, to help the students during their time in the programs, and to help them identify desirable faculty appointments. To enhance diversity in the long-term, these individuals must attain tenure and be comfortable at their employing institutions. Mentoring is one way to help. The Project encourages mentoring but could have a better system of accumulating information about who is doing mentoring, who is receiving mentoring, and could provide more guidance on how mentoring can function effectively. We suggest that the DSAs could accumulate data on who is doing mentoring, identify who would be available to mentor doctoral students and/or untenured, assistant professors and be active in linking individuals. In addition, DSA conferences could include sessions on mentoring to assist individuals in conducting mentoring in the most productive manner. We also suggest that once an identifiable system is in place, the Project could include mentoring as a topic during their November conferences.

We have discussed the Project's tangible benefits. The intangible benefits may not be quantifiable but, nevertheless, are quite evident. Its existence and its visibility prove that "good" things can happen and that dreams can be fulfilled. 


\section{AUTHOR INFORMATION}

Bill N. Schwartz, PhD, CPA Bill N. Schwartz, PhD, CPA is Distinguished Affiliate Professor of Accounting, Wesley J. Howe School of Technology Management, Stevens Institute of Technology, Hoboken, NJ 07030-5991, USA. He served on the faculties at California State University, Northridge, Arizona State University, Temple University, Virginia Commonwealth University (where he was Accounting Department Chair), Indiana UniversitySouth Bend (where he was Dean of the School of Business) and currently is Distinguished Affiliate Professor of Accounting at Stevens Institute of Technology. He was co-editor for Advances in Accounting and Advances in Accounting Education. He also was editor for Research on Accounting Ethics. He earned his doctorate at U.C.L.A. E-mail: bschwartz0109@nj.rr.com

Satina V. Williams earned her doctorate at Virginia Commonwealth University. He served on the faculty at Morgan State University and currently is an Assistant Professor of Accounting at Marist College. E-mail: satina.williams@marist.edu

W. Darrell Walden, Associate Professor and Chair, Department of Accounting, Robins School of Business, University of Richmond, Richmond, VA 23173 USA. E-mail: dwalden@ richmond.edu

\section{REFERENCES}

1. Austin, A.E. (2002). Preparing the next generation of faculty: Graduate school as socialization to the academic career. The Journal of Higher Education, 73(1): 94-122.

2. DeNeff, A. L. (2002). The Preparing Future Faculty program: What difference does it make? Washington, DC: Association of American Colleges and Universities.

3. Gaffe, J.G. (2002). The disconnect between graduate education and faculty realities: A review of recent research. Liberal Education, 88(3): 6-13.

4. Golde, C.M. and T. M. Dore. (2001). At cross purposes: What the experiences of doctoral students reveal about doctoral education. Philadelphia, PA: A report prepared for The Pew Charitable Trusts.

5. Greenberg, M. (2006). The power of academic citizenship. The Chronicle of Higher Education, 52(22): B.20-B.20.

6. Heggins, W.J. (2004). Preparing African American males for the professoriate: Issues and challenges. The Western Journal of Black Studies, 28(2): 354-364.

7. Milano, B. (2008). Taking a systematic approach. Journal of Accountancy, 205(5): 78.

8. Mitchell, T. R. (2007). The academic life: Realistic changes needed for business school students and faculty. Academy of Management Learning \& Education, 6(2): 236-251.

9. Murdock, H. (2006). The many benefits of mentoring programs. Internal Auditing, 21(6): 18-23.

10. Newman, K. (1999). Confessions of a junior faculty. Academe, 85(3): 28-33. 


\section{APPENDIX A}

\section{PhD Project Objectives}

1. Inform and educate minorities about all aspects of a business doctoral program and encourage them to follow their dream of becoming a professor.

2. Provide a nurturing support network for minorities as they navigate their doctoral program.

3. Increase the number of minority business professors who can function as role models and mentors.

4. Influence more minorities to pursue business degrees/careers.

5. Increase the number of qualified minority applicants to fill critical positions in the business disciplines.

6. Improve the preparation of all students by allowing them to experience the richness of learning from faculty with diverse backgrounds.

7. Reach the goal of a better prepared and more diversified workforce to service a diversified customer base (www.phdproject.org). 